\title{
ОСОБЛИВОСТІ РОЗСЛІДУВАННЯ ЗЛОЧИНІВ ЕКСТРЕМІСТСЬКОЇ СПРЯМОВАНОСТІ, УЧИНЕНИХ ЧЛЕНАМИ МОЛОДІЖНИХ НЕФОРМАЛЬНИХ ГРУП (ОБ'ЄДНАНЬ)
}

Бояров В. І., Ларкін М. О.

\section{ВСТУП}

Останніми роками в усьому світі спостерігається значне зростання екстремістських проявів: від таких поширених форм кримінального екстремізму, які мають вигляд пропагування національної, расової, релігійної, соціальної ворожнечі та приниження людської гідності, до такого крайнього прояву, як тероризм. Останній, у свою чергу, став безпрецедентною загрозою світовій безпеці; боротьба із цим явищем є пріоритетним завданням Організації Об'єднаних Націй (далі - ООН) та серйозною перешкодою для багатьох держав, на шляху реалізації ліберальних реформ і становлення демократичного суспільства.

Серед інших країн Україна також постійно стикається із загрозою вчинення терористичних актів, збільшенням загальної кількості інших кримінально караних проявів екстремізму, зокрема групових (масові заворушення, вандалізм, терористичні акти, порушення прав людини й ін.). Особливе занепокоєння спричиняє причетність до цих злочинних посягань різного роду молодіжних неформальних груп (об'єднань), адже молодіжний екстремізм, без перебільшення, стає «ідейною хворобою» XXI ст. Г. Лебон писав: «Як річка, що вийшла з берегів i яку не може утримати жодна гребля, ідея продовжує свій спустошливий, величний і страшний потік»1 .

Тому актуальним як для практичних працівників правоохороннихорганів, так і для вчених-криміналістів стає розроблення різних за рівнем узагальнення криміналістичних методик розслідування кримінально караних проявів екстремізму, зокрема тих, які вчиняються членами молодіжних неформальних угруповань. Водночас варто враховувати, що цей процес ускладнюється відсутністю в Україні законодавчого визначення екстремізму, екстремістської діяльності, екстремістського формування (організаціі) тощо.

1 Лебон Г. Психология народов и масс. Пер с франц. Челябинск : Социум, 2010. С. 2. 


\section{1. Загальна характеристика злочинів екстремістської спрямованості}

Традиційно екстремізм розглядають як крайнощі (у політиці, релігіï, житті й ін.). Цей термін походить від латинського extremus - «прихильність до крайніх поглядів і радикальних заходів». Визначення екстремізму й екстремістської діяльності немає в чинному кримінальному законодавстві України, хоча навіть загальнодержавна стратегія національної безпеки передбачає серед інших загроз національній безпеці України, стабільності в суспільстві у внутрішньополітичній сфері «<..> можливість виникнення конфліктів у сфері міжетнічних і міжконфесійних відносин, радикалізації та проявів екстремізмув діяльності деяких об'єднань національних меншин та релігійних громад $<\ldots>>\rangle^{2}$.

У січні 2014 р. чинний Кримінальний кодекс України доповнено ст. $110^{1}$ «Екстремістська діяльність», але вже в лютому того ж року вказана стаття вилучен з Кодексу³.

У спрощеному вигляді екстремізм можна визначити як нетолерантні погляди, які мають характер, а також діяльність переважно насильницького характеру. У філософському сприйнятті екстремізм можна визначити як специфічну форму світогляду, систему координат, що форматує структуру і стан свідомості окремих соціальних груп.

Тому під сучасне розуміння екстремістських підпадають дії досить широкого спектра: від адміністративних правопорушень до кримінально караних діянь, зокрема й такого крайнього прояву екстремізму, яким є тероризм.

Шанхайська конвенція про боротьбу з тероризмом, сепаратизмом і екстремізмом (від 15 червня 2001 р.) розглядає екстремізм як діяння, спрямоване на насильницьке захоплення влади або насильницьке утримання влади, а також на насильницьку зміну конституційного устрою держави або насильницьке посягання на громадську безпеку, зокрема організацію у вищезазначених цілях незаконних озброєних формувань або участь у них ${ }^{4}$.

Залежно від цільової спрямованості і суб'єктної діяльності екстремізм, на думку кримінологів, можна представити у трьох традиційних

\footnotetext{
2 Про основи національної безпеки України : Закон України. Відомості Верховної Ради України. 2003. № 39. Ст. 351.

3 Про внесення змін до деяких законодавчих актів України щодо припинення норм законів, схвалених 16 січня 2014 р. : Закон України № 732-VII від 28 січня 2014 р. Відомості Верховної Ради Украӥни. 2014. № 17. Ст. 593.

4 Шанхайская конвенция от 15 июня 2001 г. «О борьбе с терроризмом, сепаратизмом и экстремизмом». Собрание законодательства Российской Федерачии. 2003. № 41. Ст. 3947.
} 
формах: політичний, національний і релігійний. Національний екстремізм розглядається як намагання політичних суб'єктів, громадських організацій і окремих громадян утверджувати всілякими засобами домінування інтересів нації або етносу, до яких вони належать, на шкоду міжнаціональній єдності, аж до порушення прав і свобод людини та громадянина за ознакою національної приналежності. Релігійний екстремізм інтерпретується як нетерпимість до інших конфесій або утвердження переваг представників однієї з конфесій 5 .

У науковій літературі згадується багато інших за назвою видів екстремізму: молодіжний, насильницький, ісламський, екологічний, регіональний та ін. - понад 20, а у Сполучених Штатах Америки (далі США) традиційно виділяють фактично лише два виду екстремізму: лівий та правий (окремо - фашизм і радикалізм). Але, на нашу думку, найбільш типовими для назви цього явища є характеристики екстремізму як молодіжний і насильницький.

Саме для молоді як резерву маргінального середовища, яке, у свою чергу, є резервом поповнення молодіжних (неформальних) екстремістських об'єднань, для особи характерна невизначеність стану, поглядів на те, що відбувається в соціально дезорієнтованій частині суспільства тощо. У цьому середовищі має місце низький рівень самоповаги та наявні умови, які сприяють ігноруванню прав особи.

В умовах відсутності в чинному кримінальному законодавстві України визначення екстремізму як кримінально карані прояви екстремізму розглядають три великі групи кримінальних правопорушень: (1) кримінально карані діяння, які посягають на основи та безпеку політичного устрою (ст.ст. 109, 110, 111, 113 Кримінального кодексу (далі - КК) України); (2) злочини терористичного характеру (ст.ст. 112, 258, 258 $, 258^{2}, 258^{3}, 258^{4}, 258^{5}, 260,261,278,442$, 443, 444 КК України); (3) злочини екстремістської спрямованості, які вчиняються з мотивів ненависті або ворожнечі стосовно осіб, які належать до певної етнічної, расової, релігійної, політичної та іншої соціальної групи (п. 14 ч. 2 ст. 115, ч. 2 ст. 121, ч. 2 ст. 122, ч. 2 ст. 126 , ч. 2 ст. 127 , ч. 2 ст. 129 , ст. 161 та ст. 300 КК України $)^{6}$.

Злочини, зазначені в останній групі, - злочини на підгрунті ненависті та нетерпимості. Цей термін з'явився у 80-х рр. минулого

\footnotetext{
5 Лабунец М. Политический экстремизм: этнонациональная регионализация : автореф. дис. ... канд. политолог. наук: 23.00.02. Ростов-на-Дону, 2002. С. 9-10.

6 Бояров В. Криміналістична класифікація кримінально-караних проявів екстремізму. Вісник Академії адвокатури України. 2015. Т. 12. Ч. 2 (33). С. 211-212.
} 
сторіччя, а вперше був офіційно вжитий в Організації з безпеки і співробіництва в Свропі (далі - ОБСС) на засіданні Ради міністрів у 2003 р. (Маастріхт).

Ідеться зазвичай про злочин проти життя, здоров'я або приватної власності, об'єкт якого був обраний через дійсний або уявний зв'язок потерпілого із групою, що характеризується спільними ознаками ідентичності (існуюча або уявна раса; національне або етнічне походження; мова, колір шкіри, релігія, стать, вік, психічні або фізичні особливості, сексуальна орієнтація або будь-який інший аналогічний чинник $)^{7}$.

Законодавча конструкція «з мотивів расової, національної чи релігійної нетерпимості» з'явилася в Україні, коли в листопаді 2009 р. до чинного КК України були внесені зміни та доповнення до деяких статей ${ }^{8}$ Зокрема, посилання на зазначений мотив з'явилися в ч. 2 ст. 121 , ч. 2 ст. 122 , ч. 2 ст. 126 , ч. 2 ст. 127 , ч. 2 ст. 129, а також у ст. 161 та ст. 300 КК України (в останній зроблена вказівка на «твори, що пропагують расову, національну чи релігійну нетерпимість та дискримінацію»). У ч. 2 ст. 115 КК України з'явився новостворений п. 14, де передбачається відповідальність за вчинення умисного вбивства 3 мотивів расової, національної чи релігійної нетерпимості ${ }^{9}$ [9, с. 174]. Серед інших обставин, які обтяжують покарання, чинний КК України (п. 3 ч. 1 ст. 67) визнає вчинення злочину на грунті расової, національної чи релігійної ворожнечі або розбрату.

На практиці здебільшого йдеться про насильницькі злочини: групові порушення громадського порядку, які можуть перетворитися на масові заворушення; безпосередньо масові заворушення (які, як відомо з подій останніх років, у деяких країнах закінчувалися «кольоровими» революціями та зміною влади); злочини, що вчиняються зазвичай молодіжними неформальними угрупованнями з мотивів расової, національної чи релігійної ворожнечі, та деякі інші діï, учинення яких пов'язане зі створенням нестабільності життя для окремих громадян у країні та висуненням державі з боку окремих

\footnotetext{
7 Преступления на почве ненависти в регионе ОБСЕ: инциденты и меры реагирования. Годовой отчет Бюро по демократическим институтам и правам человека ОБСЕ. URL: http://www.osce.org/publications/odihr/2007/09/26296_931_ru.pdf.

8 Про внесення змін до Кримінального кодексу України щодо відповідальності за злочини з мотивів расової, національної чи релігійної нетерпимості : Закон України від 5 листопада 2009 р. Відомості Верховної Ради Украӥни. 2010. № 5. Ст. 43.

Савченко А. Вплив мотивів расової, національної чи релігійної нетерпимості на кваліфікацію злочинів. Вісник Академії адвокатури Украӥни. 2010. Ч. 1 (17). С. 174.
} 
осіб і угруповань різного роду вимог, зокрема щодо змін у діяльності влади, політики уряду тощо.

Під злочинами екстремістського спрямування розуміються кримінально карані діяння, які вчиняються за мотивами політичної, ідеологічної, расової, національної або релігійної ненависті чи ворожнечі. Отже, мотив (як і ціль) є обов'язковою ознакою суб'єктивної сторони злочинів екстремістської спрямованості. За всього розмаїття мотивації вчинення злочинних дій основним мотивом виступає той, що є найбільш сильним. Деякі дослідники цього питання пропонують виділяти як спонукальні до конкретної поведінки особи мотиви трьох порядків: цільові, орієнтуючі та технічні ${ }^{10}$. Для такого різновиду проявів екстремізму, якими є злочини на грунті ненависті, цільовим мотивом буде виступати, наприклад, прагнення до витіснення суб'єктів - представників іншої національності, раси із соціальної реальності. Орієнтуючим мотивом водночас буде виступати «презумпція винуватості» осіб, що належать до конкретної групи, а технічний мотив буде конкретизувати мотиви попередніх рівнів уже в реальній ситуації ${ }^{11}$. Саме тому, за наявності ідеологічної складової частини в діях таких осіб (ідеологічної настанови), вони фактично не приховують як сліди злочинних дій, так і їх мотивацію. Саме це, а не об'єкт кримінально-правової охорони, поєднує ці злочини в єдину групу 12 .

До тенденцій розвитку кримінального екстремізму, які характерні для нашої країни, можна віднести: по-перше, формування стійких соціальних груп, які підтримують ідеологію екстремізму; по-друге, формування в суспільстві переконань про допустимість застосування насильства для вирішення різного роду конфліктів; по-трете, інституціоналізацію і легалізацію молодіжних (неформальних) екстремістських організацій, їхніх лідерів, проникнення таких організацій та їхніх членів у політичну еліту країни ${ }^{13}$.

\footnotetext{
10 Скляров С. Мотивы индивидуального преступного поведения и их уголовно-правовое значение. Москва, 2000. С. 67-68.

11 Методика расследования преступлений, совершенных на почве национальной или расовой вражды или ненависти / А. Винников и др. ; под общ. ред. О. Коршуновой. СанктПетербург, 2002. С. 26.

12 Кулешов Р. Преступления в сфере экстремистской и террористической деятельности: механизм совершения и концептуальные положения оптимизации методики их расследования : монография. Ростов-на-Дону : Альтаир, 2017. С. 39.

13 Бурковская В. Криминальный религиозный экстремизм: уголовно-правовые и криминологические основы противодействия : автореф. дис. ... докт. юрид. наук: 12.00.08. Москва, 2006. C. 12.
} 
Усе це призводить не тільки до створення молодіжних неформальних об'єднань екстремістського спрямування (фан-групи, етнічні, націоналістичні й інші об'єднання молоді), але й створює в суспільстві обстановку активної підтримки дій молодіжних неформальних екстремістських формувань, послідовно створюючи умови для «масованої» протидії розслідуванню, ускладненої тим, що держава побоюється визнавати наявність у країні молодіжних екстремістських організацій, поширення екстремістської ідеології, навіть коли це є очевидним, а обстановка розслідування може бути ускладнена повною або частковою паралізацією влади.

\section{2. Планування розслідування злочинів екстремістської спрямованості, учинених членами молодіжних неформальних груп (об'сднань)}

Саме від якості планування початкового етапу розслідування злочинів, які вчиняються учасниками молодіжних неформальних груп (об’єднань), зокрема екстремістської спрямованості, багато в чому залежить, чи будуть викриті винні особи. Великого значення в цей період розслідування набуває правильна оцінка виявлених доказів. Помилка в цій момент уведе розслідування в неправильному напрямі та спричинить непоправні втрати часу ${ }^{14}$.

Тому під час планування розслідування зазначених злочинів необхідно враховувати таке:

1. Характерною особливістю злочинної діяльності неформальної молоді (зокрема, учасників формувань екстремістського спрямування) $\epsilon$ те, що вона демонстративна, і члени груп фактично не роблять спроб iï приховати, тобто для слідчої ситуації початкового етапу розслідування характерна очевидність, що дає можливість висунути версію про вчинення злочину членами молодіжної неформальної групи екстремістської спрямованості. Залежно від аналізу слідів, залишених на місці злочину, версія може бути уточнена в частині різновиду неформального об'єднання та його цілей. Варто враховувати, що «неформалами» можуть вчинятися злочини, які не пов'язані $з$ «ідеологією» групи, об'єднання, а спрямовані на створення умов для ії функціонування (наприклад, крадіжки, грабежі, торгівля наркотичними засобами й ін.), або злочини, які взагалі не пов'язані з існування неформального співтовариства (наприклад, злочини проти особи з мотивів особистої

\footnotetext{
14 Лобунец Е. Назначение и содержание этапов расследования преступлений : монография / под общ. ред. Н. Мерецкого. Москва : Юрлитинформ, 2015. С. 54.
} 
неприязні й ін.). Аналізуючи конкретну слідчу ситуацію, важливо розпізнавати вказані види злочинів.

2. Досліджуючи матеріально-фіксовану сторону злочинів, які вчиняються неформальною молоддю, особливу увагу необхідно приділяти слідам, які вказують на те, що злочин скоєний угрупованням із певними поглядами, ідеями та переконаннями.

3. Під час здійснення перевірки версій, висунутих слідством, варто ретельно допитати осіб, які $є$ безпосередніми свідками злочинних подій, що $є$ предметом розслідування, оскільки їхні свідчення можуть допомогти встановити мотив вчинення того чи іншого злочину, ідентифікувати неформальну групу (екстремістське формування), виявити особливості спілкування та дій ії членів.

4. Зважаючи на специфіку вказаних злочинів, може виникнути необхідність у проведенні не тільки традиційних для насильницьких злочинів судових експертиз, але й таких експертиз, як судово-психологічна, судово-лінгвістична, конфліктологічна експертиза ситуації в регіоні, завдяки яким можна отримати інформацію про мотивацію вчинення злочинних дій тощо.

У плануванні треба враховувати також те, що початковий етап розслідування часто проходить в умовах повної або часткової паралізації досудового слідства (зокрема, правоохоронних органів і суду), а це спричиняє неможливість проведення першочергових і невідкладних слідчих (розшукових) дій; підвищується ризик втрати речових доказів та ін.; а те, що багато пересічних громадян країни поділяють ідеологію, обрану молодіжним екстремістським формуванням, або в яких сформоване уявлення про «обличчя ворога» (певні екстремістські дії частиною населення розглядаються як справедливі), яке поділяється й учасниками екстремістського формування, позбавляє слідство свідків і потерпілих, які б виступали на боці обвинувачення.

\section{3. Тактика проведення окремих слідчих (розшукових) дій} під час розслідування злочинів екстремістської спрямованості, учинених членами молодіжних неформальних груп (об'єднань)

Метою огляду місця подіï в зазначених кримінальних провадженнях є: виявлення слідів правопорушення та речових доказів; 3'ясування обставин події, яка $є$ предметом розслідування; інших обставин, які мають значення для провадження (дані про осіб - очевидців, учасників і організаторів події, про потерпілих, а також висунення версій про подію, яка є предметом розслідування). 
Негативною обставиною, якою характеризується такий огляд, є те, що в зазначених провадженнях інколи немає можливості невідкладно провести цю слідчу (розшукову) дію. Часто це пов'язане із продовженням групових злочинних дій, коли немає гарантій безпеки для учасників огляду; є багато об’єктів огляду і немає достатньої кількості слідчих, оперативних працівників та спеціалістів для проведення негайного огляду. Так, за статистикою (Радянський Союз - Україна, 1988-2002 рр.), у день учинення, наприклад, масових заворушень огляд місця події проводився лише за кожною восьмою справою; у майже $60 \%$ справ огляд проводився через день-два, а у $30 \%$ справ узагалі не проводився ${ }^{15}$. Несвоєчасне проведення огляду призводить до таких негативних наслідків, як внесення змін до обстановки місця події, крадіжок майна потерпілих у місцях, які були об'єктом нападу; втрати речових доказів тощо.

Є кілька найбільш типових місць, які підлягають першочерговому огляду в таких провадженнях: місце збору групи, ділянки місцевості за маршрутом їі руху до місця вчинення злочинів, місця вчинення злочинів (місце, де група могла бути розсіяна співробітниками правоохоронних органів (із застосуванням спеціальних засобів), також).

У підготовчій стадії огляду як важливий iї елемент виділяють загальний огляд місця події, який передбачає такі організаційно-підготовчі заходи: встановлення меж місця події, у процесі якого виявляється характер учинених дій; з урахуванням характеру місцевості й інших чинників визначається порядок просторового охоплення місця події та пересування учасників огляду; вирішується питання про організацію роботи учасників огляду, розподіл їхніх обов'язків; проведення заходів, спрямованих на збереження слідів на місці події; вирішення питання про застосування технічних засобів, які доцільно використовувати на місці події ${ }^{16}$.

Якщо йдеться про злочини, які охоплюють велику територію, під час загального огляду використовують гелікоптер або безпілотний летальний апарат (далі - БПЛА), що, за допомогою застосування відеозапису, аерофотознімання надає можливість для

\footnotetext{
15 Шаталов А. Технико-криминалистическое обеспечение раскрытия и расследования преступлений, совершенных в условиях массовых беспорядков : дис. ... канд. юрид. наук: 12.00.09. Москва, 1993. С. 42 ; Шалдирван П. Методика розслідування масових заворушень : дис. ... канд. юрид. наук: 12.00.09. Київ, 2005. С. 104.

16 Степанов В. Современные проблемы осмотра места происшествия. Влияние идей И.Н. Якимова на развитие современной криминалистики : сборник материалов Международной научно-практической конференции. Москва, 2014. С. 90-91.
} 
отримання інформації про наслідки групових злочинних дій у населеному пункті або регіоні. У результаті такого огляду (обльоту) створюється схема місць подій, які потребують детального огляду (зокрема, залишені автомашини, трупи, місця пожеж тощо).

Демонстрація підготовленого таким чином відеозапису дає учасникам наступних оглядів необхідне уявлення щодо місць, які будуть об'єктами огляду.

Підготовчі дії, які передують огляду за кримінальними провадженнями цієї категорії, пов’язані з вирішенням питання щодо кола осіб, які братимуть участь в огляді, як-от: судово-медичний експерт, експерт-криміналіст ${ }^{17}$, спеціаліст пожежного нагляду, вибухотехнік та ін. Це також можуть бути власники об'єктів, які зазнали пошкоджень, погромів, знищення майна.

Крім того, слідчий повинен безпосередньо контактувати зі спеціалістом, який вивчає формування і діяльність молодіжних неформальних груп (об’єднань, рухів тощо), для негайної фіксації специфічних слідів, залишених неформалами. Саме специфічні сліди дають підстави висунути версію, що злочин учинено представниками молодіжного неформального середовища, або навіть конкретизувати, яким саме.

До загальних рекомендацій з огляду місця події за такими кримінальними провадженнями належать: обов'язковий пошук і вилучення речей, які використовували під час учинення насильницьких дій як зброю для руйнування або пошкодження об'єктів нападу, травмування потерпілих, опору представникам влади: металеві прутки, біти (кійки), фрагменти пошкоджених меблів (наприклад, ніжки від стільців або столів, які зручні для нанесення ударів), каміння, різноманітні металеві предмети, зокрема промислового виробництва і призначення (болти, гайки великих розмірів, трубки й ін.), оскільки на них можуть залишитися відбитки пальців рук підозрюваних, залишки скла, біологічні речовини й ін.; ємності або їх фрагменти із залишками запалювальної суміші тощо.

Звертається увага на наявність слідів крові на грунті, метальних снарядах, уламках скла (підлягають вилученню). Це можуть бути як наслідки дій осіб, які захищали своє майно, так і наслідки застосування зброї правоохоронними органами або наслідки отримання травм

\footnotetext{
17 Інструкція про порядок залучення працівників органів досудового розслідування поліції та Експертної служби МВС України для участі в проведенні огляду місця події : наказ Міністерства внутрішніх справ України від 1 лютого 2015 p. № 1339. URL: https://zakon.rada. gov.ua/go/z1392-15 (дата звернення: 15.02.2020).
} 
учасниками групових злочинних дій через падіння скла вітрин, дій охорони та власників об'єкта нападу тощо.

Допит потерпілих. До особливостей, які ускладнюють процес розслідування кримінально караних проявів екстремізму неформальної молоді, можна віднести досить поширене небажання більшості потерпілих (переважно із числа осіб, які входять до «груп ризику») повідомляти про злочин, а отже, і продуктивно контактувати зі слідством із метою встановлення та викриття винних осіб.

Саме потерпілий у таких провадженнях є одним із головних джерел інформації, яке має значення для ефективного розслідування, оскільки така особа: повідомляє про злочин, є очевидцем злочинних дій, має на собі сліди, наприклад, насильницьких дій, і саме від неї, на початковому етапі розслідування, залежить не тільки внесення відповідних даних до Єдиного реєстру досудових розслідувань (далі - СРДР), але й встановлення всіх обставин злочину, винних осіб і мотивації їхніх дій.

У результаті, на початковому етапі розслідування таких справ може скластися така слідча ситуація: є повідомлення про насильницькі дії стосовно кількох осіб, внесені відповідні дані до СРДР, є інформація щодо мотивації нападу, але не відомі особи нападників та не відомі більша частина осіб, які є жертвами цього нападу.

Тому важливо не тільки оперативно встановити жертв злочинних дій, але й знайти з ними продуктивний контакт, що дозволить слідству (обвинуваченню) отримати всю необхідну для розслідування інформацію.

Для залучення до розслідування жертви злочину слідчий повинен надати їй гарантії безпеки в разі, якщо потерпілий буде співпрацювати з обвинуваченням, а отже, буде сприяти викриттю винних осіб.

У результаті проведення підготовчих заходів допит потерпілих може проходити в умовах безконфліктної ситуації, коли основним завданням слідчого буде підтримання безконфліктної ситуації, а основним тактичним прийомом буде виступати використання «вільної розповіді» потерпілого.

Питання, що підлягають встановленню під час допиту потерпілого, стосуються, по-перше, інформації щодо особи жертви, а по-друге, встановлення обставин вчинення злочину. Щодо особи жертви: про громадянство, вік, вид діяльності, володіння мовою країни перебування (якщо, наприклад, потерпілий є іноземцем), про належність до певної «групи ризику» (раса, національність, релігія (секта), молодіжна 
контркультура (готи й ін.), сексуальна меншина, зайняття забороненою діяльністю й ін.). Встановлюються місця проживання, роботи, відпочинку, спілкування; інші місця постійного або тимчасового перебування, фіксовані маршрути пересування й ін.

Щодо обставин злочину: кількість осіб, які його вчинили; їхні прикмети, озброєність (особливості одягу, наявність і зміст татуювання, символіка (наприклад, наявність шевронів) та ін.); наявність особи, яка (на думку потерпілого) керувала злочинними діями групи; расова, національна етнічна належність нападників і особливості їх спілкування один $з$ одним (якою мовою розмовляли); які погрози (їхній зміст) висловлювалися стосовно потерпілого тощо ${ }^{18}$.

Важлива інформація щодо нападів або інших інцидентів, пов'язаних з аналогічними злочинними діями, які мали місце раніше (про які правоохоронним органам нічого не було відомо, наприклад). Хто був жертвою попередніх нападів, де і коли це сталося, які тілесні ушкодження спричинені, чи зверталися жертви до медичних закладів тощо.

Лише після проведення допиту слідчий, з урахуванням подальшої перспективи продуктивного співробітництва з потерпілим (чи буде він брати участь у судовому засіданні, чи залишить країну після дачі показань), вирішує питання про доцільність пред’явлення підозрюваних для впізнання.

Допит свідків. Допит свідка $є$ обов'язковою та найбільш поширеною слідчою (розшуковою) дією під час розслідування злочинів. Основною метою допиту є одержання нової, раніше не відомої слідству, інформації щодо предмета доказування, а також підтвердження або спростування інформації, яку отримало слідство, але яка ще не перевірена, тому не може вважатися достовірною.

У кримінальних провадженнях про екстремістську діяльність можна виокремити такі типові групи свідків: (1) свідки, які є очевидцями події, що є предметом розслідування, зокрема свідки, які є й очевидцями діяльності екстремістського формування (угруповання) та мають інформацію про iіi членів; (2) свідки, які опосередковано поінформовані (наприклад, через інших осіб) про подію, яка є предметом розслідування, або про діяльність екстремістського угруповання, або про потерпілих; (3) свідки, які поінформовані про обставини затримання учасників подій або про готування до вчинення злочину; (4) свідки, які

\footnotetext{
18 Капица В. Расследование преступлений против жизни и здоровья, совершенных по мотиву национальной, расовой, религиозной ненависти или вражды : автореф. дис. ... канд. юрид. наук: 12.00.09. Краснодар, 2009. С. 19-20.
} 
раніше входили до складу екстремістської організації (угруповання), але в подальшому добровільно залишили її склад (наприклад, не погоджуючись з ідеологією, яка поєднує членів організації).

Основним завданням слідчого стосовно очевидців є отримання інформації про вчинений злочин: хто (кількість учасників, прикмети), коли, які саме злочинні дії та за якою мотивацією; яку зброю застосовували, про дії жертв, про приховування слідів; про дії представників правоохоронних органів та ін.

Стосовно свідків, які опосередковано поінформовані про подію, основним завданням слідчого є отримання інформації про очевидців, про потерпілих (жертв), інформацію щодо молодіжного неформального екстремістського угруповання (склад, лідери, місця дислокації, відомі злочинні дії тощо).

Украй важливе отримання показань від осіб, які раніше входили до складу екстремістської організації. Під час їх допиту встановлюються обставини створення такої специфічної групи (об'єднання), яким $\epsilon$ екстремістське формування, й обставини, за яких свідок був залучений до діяльності групи; як проходив перехід від аполітичної діяльності формування до сприйняття певної екстремістської ідеології, інші трансформації; про джерела фінансування; про структуру і керівників (ідеологів), активних учасників (членів) угруповання; про вчинення конкретних акцій та ін.

Треба зазначити, що допит свідків-очевидців, який негайно проводиться після події (по гарячих слідах), практично не викликає якихось ускладнень, фактично є безконфліктним. Важливим є додатковий допит, пов'язаний, наприклад, із необхідністю пред'явлення для впізнання або проведення одночасного допиту двох чи більше вже допитаних осіб для з'ясування причин розбіжності в їхніх показаннях тощо.

Нестабільність пов'язана з тим, що в сучасних умовах, коли існує феномен посткримінального впливу, держава не може створити безпечні умови свідкам, які дають показання, що викривають винних. Отже, коли свідок дає саме такі свідчення, це ставить його, а також його близьких, у скрутне становище - під загрозою опиняється їхнє життя, здоров'я, майно (особливо коли він викриває учасників екстремістських або організованих злочинних угруповань). Саме в таких ситуаціях слідчий проводить тактичну операцію «Захист свідків».

Допит nідозрюваного. Допит підозрюваних у зазначеній категорії проваджень завжди проходить в умовах тактичного ризику. 
Складність і специфіка допиту підозрюваних, які входять до складу екстремістського неформального співтовариства (організації, угруповання), пов'язані з попередніми домовленостями таких осіб дотримуватися конкретної лінії поведінки на слідстві, проходження ритуалу присяги про нерозголошення інформації про діяльність організації тощо. Для зазначених осіб характерна наявність специфічної мотивації дій, зазвичай не корисливої, а на грунті ненависті, - учасники таких об'єднань (угруповань) частіше за все поєднані на основі певної ідеології (фашизм, націоналізм, антисемітизм та ін.).

Допиту підозрюваного передують інші слідчі (розшукові) і процесуальні дії. Зокрема, затримання за підозрою у вчиненні злочину, освідування, допит потерпілих і свідків; інформація, отримана в результаті проведення оперативно-розшукових заходів, або інформація, яка накопичена у відповідних базах даних, щодо екстремістських, терористичних організацій, організованих злочинних угруповань. Усе це сприяє підготовці до допиту підозрюваного, яка для зазначеної категорії проваджень включає: вивчення особи підозрюваного; знання особливостей поведінки осіб, які вчиняють такі злочини, розуміння субкультури злочинних угруповань екстремістської спрямованості.

Інформацію про підозрюваного можна також отримати на основі аналізу інформації про осіб, для яких ключові канали споживання інформації - Інтернет, соціальні мережі, відеосервіси, які брали участь в обговоренні в Мережі актуальних питань сьогодення і висловлювали, наприклад, підтримку якоїсь ідеологічної настанови, носієм якої $\epsilon$ «лідер думок», що на своєму сайті поєднує однодумців.

Традиційно це допит у конфліктній ситуації. Ефективним тактичним прийомом є використання показань співучасників, інформації, отриманої під час обшуків, допитів свідків і потерпілих, даних з Інтернету, камер відеоспостереження й ін.

Під час допиту підозрюваних у вчиненні злочинів, які є проявом екстремістської діяльності, у безконфліктних ситуаціях (або в разі подолання такої ситуації та налагодженні психологічного контакту) потрібно встановлювати такі (крім анкетних даних) обставини: про характер, спрямованість особистості, особливості виховання особи в родині, школі (для встановлення джерел формування особистості); ставлення підозрюваного до оточення, зокрема за національною ознакою, расовими ознаками й ін.; чи не $є$ він прибічником учень про поділ націй і рас на вищі, обрані та неповноцінні; яку літературу читає; наявність хобі, рівень матеріальної забезпеченості (джерела 
і розмір офіційних доходів); чи брав участь раніше в конфліктах на грунті ненависті або ворожнечі (чи не притягувався до кримінальної або адміністративної відповідальності); чи не $\epsilon$ він членом якоїсь організації, угруповання, яке об'єднує своїх учасників на основі сприйняття спільної ідеології; як вступив до організації, іiї структура, лідери, джерела фінансування, акції, які проводить організація, обставини їх проведення й участь у них тощо.

Не рекомендується під час допиту осіб, які входять до складу молодіжної неформальної екстремістської організації, яка має ідеологічний складник, переводити допит у русло заперечення догм, які покладені в основу такої ідеології (аналогічна ситуація виникає у справах про діяльність деструктивних сект, тоталітарних культів, де спір про віру часто призводить до відмови особи від дачі показань і не сприяє створенню відповідного контакту між слідчим і допитуваним).

Використання спеціальних знань. У процесі розслідування зазначеної категорії кримінальних проваджень слідчий не може нехтувати двома формами спеціальних знань, а саме: 1) залученням спеціалістів до проведення слідчих (розшукових) дій; 2) призначенням судових експертиз. Ідеться про спеціальні знання в галузі судової медицини, лінгвістики, історії, релігії, політології, етнології, психології, психіатрії, авторознавства й ін.

Найбільш поширене використання спеціальних знань шляхом залучення спеціалістів для проведення огляду місця події. Під час проведення інших слідчих (розшукових) дій залучаються психологи (проведення допиту, наприклад, неповнолітніх підозрюваних, свідків або потерпілих), релігієзнавці (огляд літератури; дослідження текстів, вилучених під час обшуків) та ін.

Під час розслідування екстремістських проявів неформальної молоді слідчий може скористатися допомогою спеціалістів у проведенні огляду місця події (судово-медичний експерт; експерт-криміналіст; спеціаліст із вибухознавства; спеціаліст-біолог; фахівець, який вивчає формування і діяльність молодіжних неформальних утворень тощо), допиту підозрюваного, свідків, потерпілих (спеціаліст-психолог; спеціаліст, який вивчає формування та діяльність молодіжних неформальних утворень тощо), обшуку (судово-медичний експерт; експерт-криміналіст; спеціаліст-біолог; спеціаліст-товарознавець; спеціаліст із комп'ютерної техніки; спеціаліст, який вивчає формування і діяльність молодіжних неформальних утворень тощо). 
Експертизи ж у кримінальних провадженнях, у вчиненні яких підозрюються члени молодіжних неформальних груп (об'єднань), за загальним правилом, можна розділити на дві групи: загальні (типові) та спеціальні. До першої групи варто віднести науково-експертні дослідження, які притаманні розслідуванню злочинів, у яких завдано шкоди життю та здоров'ю особи: судово-медичні, судово-психіатричні, судово-біологічні, окремі криміналістичні (трасологічна, балістична, дактилоскопічна, почеркознавча) та деякі інші експертизи. До другої групи, на нашу думку, варто віднести судово-лінгвістичні, судовопсихологічні, психолінгвістичні, авторознавчі, технічні, експертизи матеріалів відеоспостереження й інші експертизи.

Інші слідчі (розиукові) та процесуальні діі. Процес розслідування зазначеної категорії кримінальних проваджень повинен проходити в умовах постійної і продуктивної співпраці з підрозділами, які є суб' єктами Закону України «Про оперативно-розшукову діяльність» і які на підставі доручення слідчого, прокурора проводять оперативно-розшукові заходи, спрямовані на встановлення та викриття винних осіб, очевидців, потерпілих, документів і речових доказів.

Проводяться також обшуки, тимчасове вилучення документів, освідування й інші процесуальні дії.

\section{ВИСНОВКИ}

На основі вивчення емпіричного матеріалу, літературних джерел нами проаналізовані особливості розслідування злочинів екстремістської спрямованості, учинених членами молодіжних неформальних груп (об’єднань). Наголошується, що досить актуальним як для практичних працівників правоохоронних органів, так і для вчених-криміналістів стає розроблення різних за рівнем узагальнення криміналістичних методик розслідування кримінально караних проявів екстремізму, зокрема тих, які вчиняються членами молодіжних неформальних угруповань. Варто водночас ураховувати, що цей процес ускладнюється відсутністю в Україні законодавчого визначення екстремізму, екстремістської діяльності, екстремістського формування (організаціі) тощо.

Від якості планування початкового етапу розслідування злочинів, які вчиняються учасниками молодіжних неформальних груп (об’єднань), зокрема екстремістської спрямованості, багато в чому залежить, чи будуть викриті винні особи. Визначенні окремі питання планування розслідування в зазначеній категорії злочинних посягань. 
Розглянуті проблемні питання огляду місця події. Метою огляду місця події в зазначених кримінальних провадженнях є: виявлення слідів правопорушення та речових доказів; з'ясування обставин події, яка $є$ предметом розслідування; інших обставин, які мають значення для провадження (дані про осіб - очевидців і учасників, організаторів події, про потерпілих, а також висунення версій про подію, яка є предметом розслідування).

Встановлена специфіка допиту окремих учасників зазначених кримінальних проваджень (потерпілого, свідка). Підкреслюється, що у процесі розслідування екстремістських проявів неформальної молоді слідчий не може нехтувати двома формами спеціальних знань, а саме: 1) залученням спеціалістів до проведення слідчих (розшукових) дій; 2) призначенням судових експертиз.

Запропоновані відповідні рекомендації, які можуть використовуватися на практиці.

\section{АНОТАЦІЯ}

У статті наголошується, що в останні роки в усьому світі спостерігається значне зростання екстремістських проявів: від таких поширених форм кримінального екстремізму, які мають вигляд пропагування національної, расової, релігійної, соціальної ворожнечі та приниження людської гідності, до такого крайнього прояву, як тероризм. Тому досить актуальним як для практичних працівників правоохоронних органів, так і для вчених-криміналістів стає розроблення різних за рівнем узагальнення криміналістичних методик розслідування кримінально караних проявів екстремізму, зокрема тих, які вчиняються членами молодіжних неформальних угруповань. У зв'язку із цим проаналізована загальна характеристика злочинів екстремістської спрямованості. Визначенні особливості планування розслідування злочинів екстремістської спрямованості, учинених членами молодіжних неформальних груп (об’єднань). Розглянуті проблемні питання огляду місця події. Встановлена специфіка допиту окремих категорій учасників зазначених кримінальних проваджень. Підкреслюється, що у процесі розслідування екстремістських проявів неформальної молоді слідчий не може нехтувати двома формами спеціальних знань, а саме: 1) залученням спеціалістів до проведення слідчих (розшукових) дій; 2) призначенням судових експертиз. 


\section{ЛІТЕРАТУРА}

1. Лебон Г. Психология народов и масс. Пер с франц. Челябинск : Социум, 2010. 379 с.

2. Про основи національної безпеки України: Закон України. Відомості Верховної Ради України. 2003. № 39. Ст. 351.

3. Про внесення змін до деяких законодавчих актів України щодо припинення норм законів, ухвалених 16 січня 2014 р. : Закон України № 732-VII від 28 січня 2014 р. Відомості Верховної Ради України. 2014. № 17. Ст. 593.

4. Шанхайская конвенция от 15 июня 2001 г. «О борьбе с терроризмом, сепаратизмом и экстремизмом». Собрание законодательства Российской Федераиии. 2003. № 41. Ст. 3947.

5. Лабунец M. Политический экстремизм: этнонациональная регионализация : автореф. дис. ... канд. политолог. наук: 23.00.02. Ростовна-Дону, 2002. 22 с.

6. Бояров В. Криміналістична класифікація кримінально караних проявів екстремізму. Вісник Академії адвокатури Украӥни. 2015. Т. 12. Ч. 2 (33). C. $210-216$.

7. Преступления на почве ненависти в регионе ОБСЕ: инциденты и меры реагирования. Годовой отчет Бюро по демократическими нститутам и правам человека ОБСЕ. URL: http://www.osce.org/ publications/odihr/2007/09/26296_931_ru.pdf.

8. Про внесення змін до Кримінального кодексу України щодо відповідальності за злочини з мотивів расової, національної чи релігійної нетерпимості : Закон України від 5 листопада 2009 р. Відомості Верховної Ради Украӥни. 2010. № 5. Ст. 43.

9. Савченко А. Вплив мотивів расової, національної чи релігійної нетерпимості на кваліфікацію злочинів. Вісник Академії адвокатури України. 2010. Ч. 1 (17). С. 174-177.

10. Скляров С. Мотивы индивидуального преступного поведения и их уголовно-правовое значение : монография. Москва : Изд-во РПА, 2000. 279 с.

11. Методика расследования преступлений, совершенных на почве национальной или расовой вражды или ненависти / А. Винников и др. ; под общ. ред. О. Коршуновой. Санкт-Петербург, 2002. 92 с.

12. КулешовР.Преступлениявсфереэкстремистскойитеррористической деятельности: механизм совершения и концептуальные положения оптимизации методики их расследования : монография. Ростов-на-Дону : Альтаир, 2017. 159 с.

13. Бурковская В. Криминальный религиозный экстремизм: уголовноправовые и криминологические основы противодействия : автореф. дис. ... докт. юрид. наук: 12.00.08. Москва, 2006. 56 с. 
14. Лобунец Е. Назначение и содержание этапов расследования преступлений : монография / под общ. ред. Н. Мерецкого. Москва : Юрлитинформ, 2015. 160 с.

15. Шаталов А. Технико-криминалистическое обеспечение раскрытия и расследования преступлений, совершенных в условиях массовых беспорядков : дис. ... канд. юрид. наук: 12.00.09. Москва, 1993. 176 с.

16. Шалдирван П. Методика розслідування масових заворушень : дис. ... канд. юрид. наук: 12.00.09. Київ, 2005. 201 с.

17. Степанов В. Современные проблемы осмотра места происшествия. Влияние идей И.Н. Якимова на развитие современной криминалистики : сборник материалов Международной научно-практической конференции. Москва, 2014. С. 86-91.

18. Інструкція про порядок залучення працівників органів досудового розслідування поліції та Експертної служби МВС України для участі в проведенні огляду місця події : наказ Міністерства внутрішніх справ України від 1 лютого 2015 р. № 1339. URL: https://zakon.rada.gov.ua/go/ z1392-15 (дата звернення: 15.03.2019).

19. Капица В. Расследование преступлений против жизни и здоровья, совершенных по мотиву национальной, расовой, религиозной ненависти или вражды : автореф. дис. ... канд. юрид. наук: 12.00.09. Краснодар, 2009. $25 \mathrm{c}$.

\section{Information about authors:}

Boiarov V. I., $\mathrm{Ph}$. D., Professor of Department of Criminal Procedure and Forensics Academy of Advocacy of Ukraine 27, Taras Shevchenko Boulevard, Kyiv, 01032, Ukraine

Larkin M. O., Ph. D., Associate Professor of Department of Criminal Law and Justice Zaporizhzhia National University 66, Zhukovsky str., Zaporizhzhia, 69600, Ukraine

DOI https://doi.org/10.30525/978-9934-588-43-3/1.26 